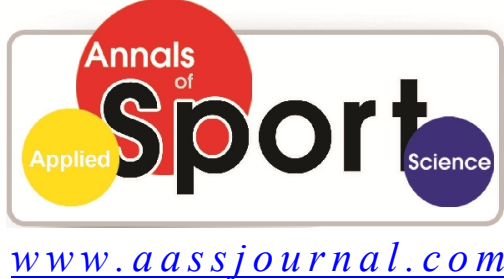

ISSN (Online): $2322-4479$

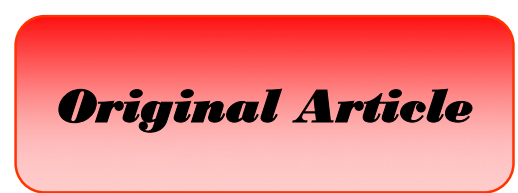

Received: 05/12/2013

Accepted: 06/02/2014

\title{
The Effects of Plyometric and Resistance Training on Explosive Power and Strength of Young Male Volleyball Players
}

\section{${ }^{1}$ Ramin Aghajani* ${ }^{2}$ Zahra Hojjati, ${ }^{2}$ Alireza Elmiyeh}

1. Department of Physical Education, Guilan Science and Research Branch, Islamic Azad University, Rasht, Iran.

2. Department of Physical Education, Rasht Branch, Islamic Azad University, Rasht, Iran.

\begin{abstract}
This paper examines the effects of plyometric and resistance training on the explosive power and the amount of young male volleyball players' strength in Guilan province. The participants include 45 volleyball players, 15-22 years old, which were randomly divided into three groups: two training groups and one control group. Among the two training groups, one was engaged in plyometric and the other in resistance exercise training (six weeks, two times per week). The control group was doing its common volleyball training. Variables under measurement consist of strength and explosive power. We found that after a six weeks training, there were significant differences between the average of explosive power and strength in both groups of plyometric and resistance training in comparison to control group $(\mathrm{P} \leq 0.05)$. The researcher observed that there was a significant difference in the average of explosive power and strength within both plyometric and weight groups from pre to post-test $(\mathrm{p} \leq 0.05)$. The amount of improvement in resistance training group was more than plyometric group.
\end{abstract}

Key Words: Explosive Power, Strength, Plyometric Training, Resistance Training.

Corresponding Author:

Ramin Aghajani

E-mail: aghajaniramin@yahoo.com 


\section{INTRODUCTION}

Volleyball is one of the most active and exciting sport. Nowadays, it has got a special place among all other ones. In this sport, the presence of aerobic and anaerobic energy and also unpredicted fluctuations of biologic needs are completely observable (1). In the modern world, athletic experts are attempting to utilize new scientific methods to prepare professional athletes at different national and international competitions. Therefore, utilization of the best appropriate methods of training is the most important basis which must be performed by the experienced in professional fields. Nowadays, there is a wide range of scientific research on athletes, competitions and physical training. In this regard, one of the most effective ways in relation to the improvement in strength and resistance increase, speed and athletes' physical energy is plyometric training (2).

One of the other long standing ways used so far is weightlifting training. Historically, these exercises were meant as the amount of physical strength. But, nowadays, people at different ages, use resistance trainings to increase their physical performance, strength and speed, prevent injuries and keep their skeletal function safety (2).

Sankey, Jones, and Bampouras (2008) have conducted a research on the effect of two plyometric training programs with different intensity on vertical jump performance among high school athletes. They concluded that 6-week plyometric training cause to improve in vertical jump performance (3). Brown et al. (2007) examined the effect of two plyometric training with weightlifting programs on aesthetic jumping ability among men at university. There was no any different between plyometric and weightlifting groups in jumping performance (4). Jothi, Vinu, and
Eleckuvan (2010) have examined the effects of a 7-week-combined resistance and plyometric program on the improvement of selected biomotor abilities. The findings revealed that feet's strength (\%4.13), resistance power $(\% 11.81)$, speed $(\% 4)$ and in anaerobic strength $(\% 7.53)$ improved after the training program. Therefore, combined resistance and plyometric training programs had statistically significant effects on the improvement of mentioned variables (5).

More efficient programs can be designed for athletes who possess physiological capabilities. Therefore, utilizing some appropriate strategies by the experts and trainers will bring desirable consequences. Similarly, the time and the cost spent for the preparation of each athlete will be decreased. Some trainer and also researchers believe that young people may be injured due to plyometric or resistance exercise. They think that growth sheets at the end of long bones may be injured and adolescents height affected by this injury. In fact resistance exercise is the same as double-edged sword. On one hand, it can promote athletic performance, and on the other, it can stop skeletal-muscle adaptation and bring injuries at growing phase in teenagers. In this way, it can result in the early and bitter separation between teenager and sport. Since weight training at this age necessitates special care and attention, and there are very few researches in this regard, this paper examines the effects of plyometric and resistance trainings with weight on explosive power of young Guilan province volleyball players.

\section{MATERIALS AND METHODS}

This study was a semi-empirical and applied research and a pretest-posttest plan with two experimental groups was used.

Subjects. forty five young male volleyball players (16-18 yrs BMI: 21.75 
$\mathrm{kg} / \mathrm{m}^{2}$ ), who participated in province matches in 1391, were studied. They were randomly divided to three equal $(n=15)$ Plyometric, resistance and control groups.

A written consent was obtained from all subjects after explanation of all phases of the test. All health parameters were considered and the participants were allowed dropping out of the research whenever they want. All tests and trainings sessions were conducted at the standard clubs in Guilan. Explosive power and isotonic strength were measured by sargent and squat tests (1RM) respectively, before and after exercise programs in three groups.

Training program. Exercise training protocols included: resistance and plyometric were conducted for six weeks, two sessions per week and 90 min (warm-up, main exercise, volleyball special training and cool down) per session. Control group was under previous exercise training. Plyometric program contained 14 various elementary and mid-level jumps (6). Resistance training included 5 stationary manner exercises with $60 \%$ one repetition maximum (1RM), 12- 15 repetition and 2-3 set.

Statistical Analysis. Descriptive statistics were used in order to describe the variables and compare the average difference in the participants' pretest and posttest. To examine the normality of the data distribution Kolmogorov-Smirnov test was used. To compare the changes in variables between three groups one way ANOVA was used. The level of significance was $p \leq 0.05$.

\section{RESULTS}

Explosive power and strength of two experimental groups increased significantly from pre to post test $(\mathrm{p} \leq 0.05)$ but there were no any significant changes in control group during the same time $(\mathrm{p}>0.05)$ (Figure 1and 2).

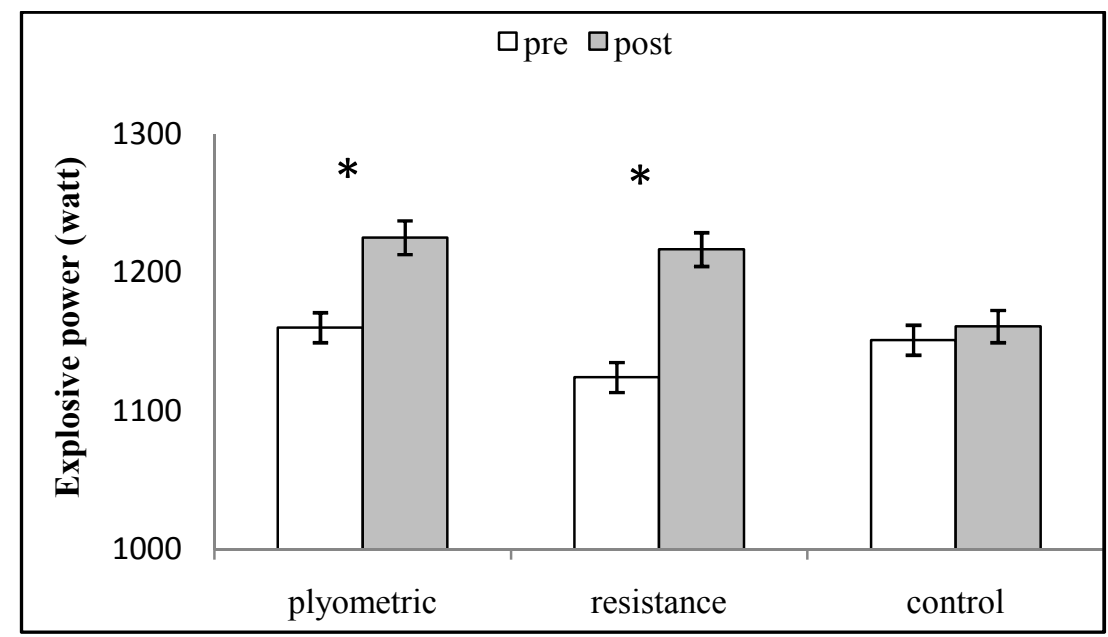

Figure 1. Explosive power in three groups from pre to post test.

*: significant increase from pre to post-test within group $(\mathrm{p} \leq 0.05)$

Table 1. Comparison resistance and explosive power changes from pre to post-test between groups

\begin{tabular}{ccccc}
\hline Variables & Group & Mean & SD & p \\
\hline \multirow{2}{*}{ Explosive Power } & Plyometric & 65.00 & 14.17 & \multirow{2}{*}{$0.001 *$} \\
$(\mathrm{~W})$ & Resistance & 92.33 & 15.79 & 6.29 \\
\hline Strength & Control & 9.73 & 12.70 & \multirow{2}{*}{$0.001 *$} \\
$(\mathrm{Kg})$ & Plyometric & 45.46 & 7.19 & \\
& Resistance & 79.93 & 1.03 & \\
\hline
\end{tabular}

*: significant difference between groups $(\mathrm{p} \leq 0.05)$. 


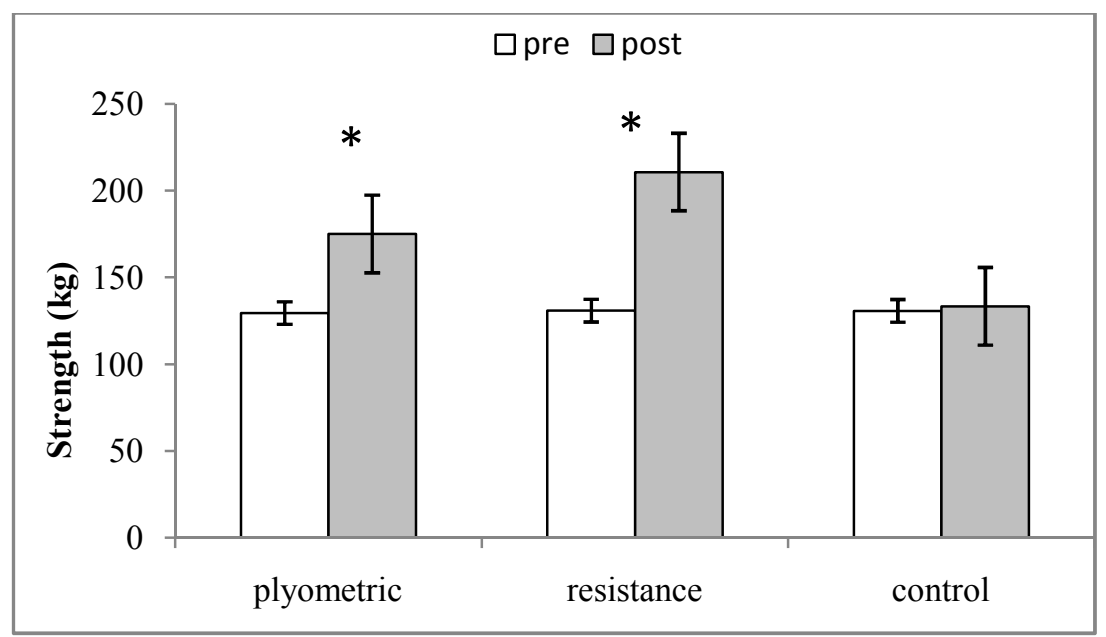

Figure 2. Strength in three groups from pre to post test. *: significant increase from pre to post-test within group $(\mathrm{p} \leq 0.05)$

As it can see in Table 1 there were significant differences in explosive power and strength changes between groups. In fact post hoc test showed that the increase of explosive power and strength in two experimental groups were significantly deference to compare with control group $(\mathrm{p}=$ 0.001).

\section{DISCUSSION}

It was evident that after six weeks plyometric and resistance training, young volleyball players have had great improvement in their skeletal strength and explosive power. In comparison to different training methods, the most improvement was observed in resistance training group and then in plyometric group.

Bosco believes that the increase in explosive power is the result of two factors: adaptation in bio motor organs and the improvement in skeletal functions to store motor energy in elastic elements. In other words, the role of plyometric training is feasibility in neural-skeletal system which results in the fast transference from external constriction to internal one (7). Therefore, increase in the strength as a result of plyometric training, may be because of the increase in the size of muscle fibers. Adaptation in the production of skeletal power is in close association with the increase in muscle fibers. Plyometric training programs cause to significant increase at the first and second type of skeletal muscle fibers (8).

Perhaps the increase in explosive power after plyometric trainings in this study, was due to neural adaptations such as: preparation of more biomotor ability, excitation of motor units with more frequency, selective utilization of motor units in adapted muscles, concurrent constriction of some muscles, the change in the speed of external and internal constriction phase and the increase in skeletal resistance and strength.

The results of this study are in line with the results of some other researches. The participants' explosive power after six-week resistance training has revealed significant increase. Weight Training can increase skeletal-muscle cross section and increases the adaptation of motor units. Although hypertrophy plays a role in the first level of resistance training, neural compatibility is of 
more importance $(9,10)$. Resistance training can increase body's ability up to $50 \%$; and then activates neural system and prepares the skeletal muscles (11). Previous studies show that the performance of resistance trainings is necessary to increase skeletal strength and speed; because it results in motor excitation and increases reflective potentials $(12,13)$. It seems that performing weight trainings with 50 to $85 \%$ intensity, results in resistance increase. Also, the participants were asked to perform the actions fast. In this way, the transference from internal phase to external phase takes less time. On the other hand, since strength is a combination of resistance and speed, with performing weight trainings, improvement in skeletal strength is evident. This study is in line with other researchers' findings.

The results of this study shows that resistance and plyometric trainings have significant effect on the strength of young volleyball payers 'feet. Also, it was found that resistance training group has got better results than plyometric group; the findings are in line with Vissing et al. (2008) (14), and in contrast with Brown et al. (2007) and MacDonald et al. (2013) $(4,15)$.

Vissing et al. (2008) examined the effects of resistance and plyometric trainings on skeletal resistance. They found that with a 12-week-training, the strength was significantly increased. This increase may be due to increase motor unit utilization. Strength among those participants, who haven't experienced resistance exercise, was most increase, because of the improvement in motor skills and the harmony in their motor units (14).
Therefore, it seems that neural factors, especially at the first few weeks are one of the most important reasons in the participants' strength improvement (10).

One of the most important parameters of resistance in association with plyometric trainings is the flexibility of skeletal muscles; i.e., its ability increase in tension. The variation range of flexibility is directly related to the ability of tissue for resistance against power and its return to its first mode when removing the exposed pressure. This is the stretched function that is utilized in plyometric training $(15,16)$.

Selected weight training in this study, provided the development in the participants' explosive power. These findings are in line with Singh (2012) (16).

Main finding of this study is that light to moderate plyometric and stationary manner resistance training on $60 \% 1 \mathrm{RM}$ can be helpful for improving in explosive power and strength. These are most important variables for volleyball skills. It seems that exercise trainings like those implicated in this study are safe and effective methods for improvement of young volleyball players' motor skills.

\section{CONCLUSION}

The research finding shows that the participants' explosive power and their skeletal resistance will have significant increase with the help of plyometric and resistance trainings. In comparison between two experimental groups, there have been significant differences, in which resistance training group have shown more improvement.

\section{REFFRENCES}

1. Laconi P, Melis F, Crisafulli A, Sollai R, Lai C, Concu A. Field test for mechanical efficiency evaluation in matching volleyball players. International journal of sports medicine. 1998;19(1):52-5. Epub 1998/03/20.

2. Aghababaei Z. A comparative Study Of the Effects Of the Selected Plyometric, Weight resistance and Plyometric weight resistance Training Methods On Leg explosive power, Lower extremity muscular Strength and Agility Of Trained Females. Rasht: Guilan University; 2010 [Thesis in Farsi].

3. Sankey SP, Jones PA, Bampouras T. Effects of two plyometric training programmes of different intensity on vertical jump performance in high school athletes. Serbian journal of sports sciences. 2008;2(4):123-30. 
4. Brown AC, Wells TJ, Schade ML, Smith DL, Fehling PC. Effects of Plyometric Training Versus Traditional Weight Training on Strength, Power, and Aesthetic Jumping Ability in Female Collegiate Dancers. Journal of Dance Medicine \& Science. 2007;11(2):38-44.

5. Jothi K, Vinu W, Eleckuvan RM. Effect of Concurrent Strength and Plyometric Training on Selected Biomotor Abilities. Recent Research in Science and Technology. 2010;2(5):124-6.

6. Vescovi JD, Canavan PK, Hasson S. Effects of a plyometric program on vertical landing force and jumping performance in college women. Physical therapy in sport : official journal of the Association of Chartered Physiotherapists in Sports Medicine. 2008;9(4):185-92. Epub 2008/12/17.

7. Bosco C, Tihanyi J, Komi PV, Fekete G, Apor P. Store and recoil of elastic energy in slow and fast types of human skeletal muscles. Acta physiologica Scandinavica. 1982;116(4):343-9. Epub 1982/12/01.

8. Luebbers PE, Potteiger JA, Hulver MW, Thyfault JP, Carper MJ, Lockwood RH. Effects of plyometric training and recovery on vertical jump performance and anaerobic power. Journal of strength and conditioning research / National Strength \& Conditioning Association. 2003;17(4):704-9. Epub 2003/11/26.

9. Carroll TJ, Riek S, Carson RG. The sites of neural adaptation induced by resistance training in humans. The Journal of Physiology. 2002;544(2):641-52.

10. Fletcher IM, Hartwell M. Effect of An 8-Week Combined Weights and Plyometrics Training Program on Golf Drive Performance. The Journal of Strength \& Conditioning Research. 2004;18(1):59-62.

11. Ebben WP, Watts PB. A Review of Combined Weight Training and Plyometric Training Modes: Complex Training. Strength \& Conditioning Journal. 1998;20(5):18-27.

12. Sale DG. Neural adaptation to resistance training. Medicine and science in sports and exercise. $1988 ; 20(5$ Suppl):S135-45. Epub 1988/10/01.

13. Staron RS, Karapondo DL, Kraemer WJ, Fry AC, Gordon SE, Falkel JE, et al. Skeletal muscle adaptations during early phase of heavy-resistance training in men and women. Journal of applied physiology (Bethesda, Md : 1985). 1994;76(3):1247-55. Epub 1994/03/01.

14. Vissing K, Brink M, Lønbro S, Sørensen H, Overgaard K, Danborg K, et al. Muscle adaptations to plyometric vs. resistance training in untrained young men. The Journal of Strength \& Conditioning Research. 2008;22(6):1799810.

15. MacDonald CJ, Lamont HS, Garner JC, Jackson K. A comparison of the effects of six weeks of traditional resistance training, plyometric training, and complex training on measures of power. Journal of Trainology. 2013;2:13-8.

16. Singh DK. Effect of Resistance Training and Plyometric Training on Explosive Strength in Adolescent Male Taekwondo Players. International Journal of Behavioral Social and Movement Sciences. 2012;1(2):49-56. 


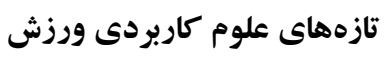

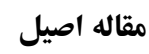

دوره دوم، شماره اول

تاريخ دريافت:

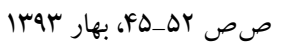

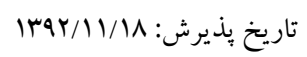

\section{اثر ات برنامه تمرين بِلايومتر يك و مقاومتى بر توان انفجارى و قدرت مردان واليباليست جوان \\ 'رامين آقاجانى *' 'زهرا حجتى، ‘عليرضا علميه}

ا. كارشناسى ارشد كروه تربيتبدنى و علوم ورزشى، دانشخاه آزاد اسلامى، واحد علوم و تحقيقات كاديقات كيلان، رشت، ايران.

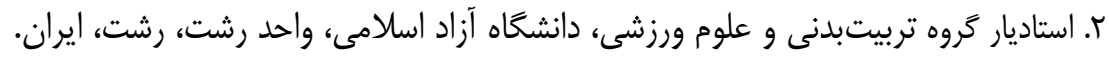

جكيده

اين تحقيق، يُوهشى نيمه تجربى است كه با هدف آثار برنامه تمرين بلايومتريك و مقاومتى بر توان انفجارى و قدرت واليباليستهاى مرد جوان

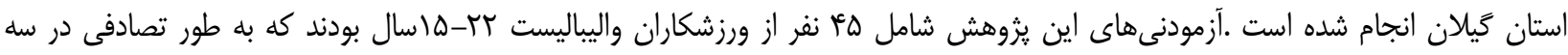

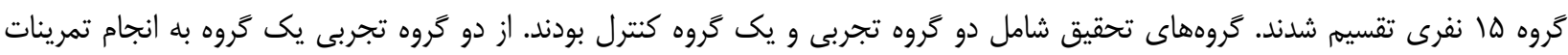

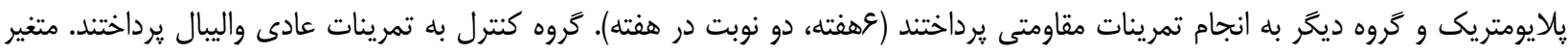

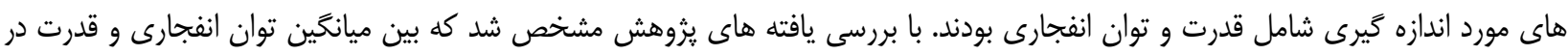

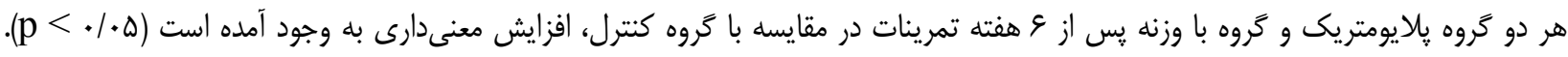

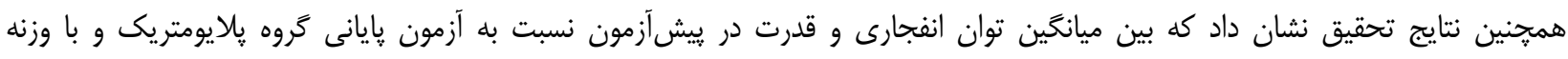

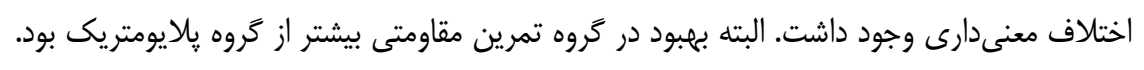
وازَّان كليدى: توان انفجارى، قدرت، تمرينات بإيومتريك، تمرينات مقاومتى. 
